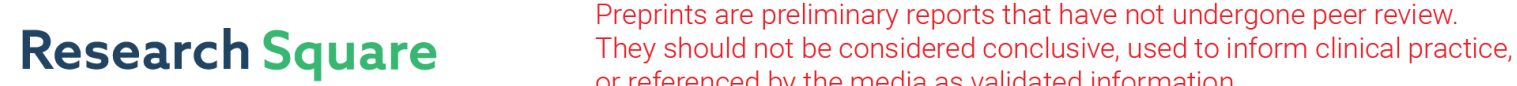 or referenced by the media as validated information. \\ Bank Climate Actions and their Implications for the Coal Power Sector: Indonesia
}

Hoy-Yen Chan ( $\nabla$ hoyyen.chan@invitegreen.onmicrosoft.com )

Invite Green Consultancy https://orcid.org/0000-0003-1263-1654

Monika Merdekawati

ASEAN Centre for Energy

\section{Beni Suryadi}

ASEAN Centre for Energy

\section{Case Report}

Keywords: Coal-fired power plant, coal financing, banking, climate change, Indonesia, coal sector development

Posted Date: October 27th, 2021

DOI: https://doi.org/10.21203/rs.3.rs-1009607/v1

License: (9) This work is licensed under a Creative Commons Attribution 4.0 International License. Read Full License 


\begin{tabular}{|c|c|}
\hline 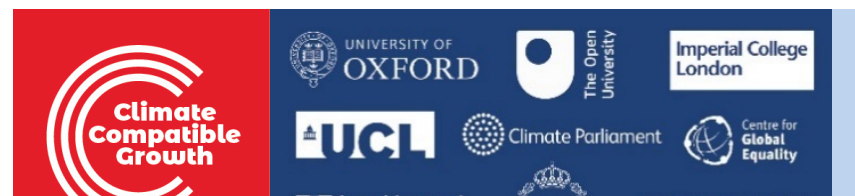 & 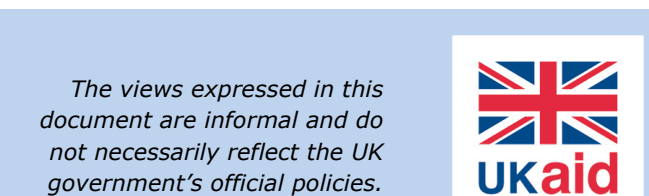 \\
\hline
\end{tabular}

\title{
Bank Climate Actions and their Implications for the Coal Power Sector: Indonesia
}

\author{
Hoy-Yen Chan*, Monika Merdekawati, and Beni Suryadi
}

\section{Key Messages}

- Banks are diversifying into climatefriendly investment portfolios

- Raising capital for coal-fired power plants will grow more difficult over time or lose financial support from present lenders

- Indonesia could turn capital raising challenges into opportunities for decarbonizing its power sector
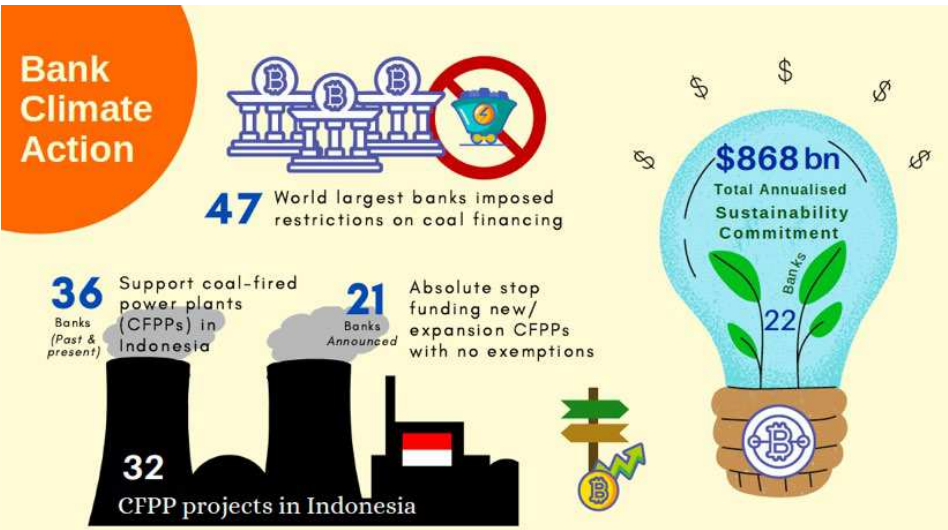

ACCEPT

\section{Introduction}

Indonesia is third, after China and India, in global coal development. Though Indonesia has made a public announcement on its carbon neutrality aspiration [1], there were no robust actions such as policy reform or a shift of energy mix. Development of the coal power sector requires capital funding for coalfired power plants (CFPPs). One of the sources of funding is through private investment banks that use loans, underwriting services, or investment to raise capital. These private funding decisions are based on creditworthiness, financing policies, and the bank's commitment to environmental, social, and governance (ESG) responsibilities.

In recent years, the nongovernmental organizations have made publications related to coal financing more available. The analysis of the data and information in such publications is crucial to understanding bank investment trends and identifying corporate greenwash. However, most of the extant publicly available data and information pertaining to coal financing is in the form of banking values, along with coal policies and discussions around banks that contribute to CFPP development. Hence, in this study, we analysed the evolution trend of bank policies on CFPP financing restrictions after adoption of the Paris Agreement and the implications of this trend for raising capital. We selected Indonesia, a country that highly depends on coal power as an example for building our arguments. This briefing summarizes our evidence and policy recommendations in response to two research questions:

1. What are the potential financial risks of raising capital for CFPPs through funding from investment banks?

2. To what extent have banks committed to sustainability compared to their fossil fuels investment?

\section{Method}

Firstly, we gathered information on the largest banks around the world that have been financing CFPPs and with restriction policies [2-4], yielding 47 banks in total. Bank policies on coal financing restrictions and their sustainability commitments were obtained from their websites. Next, we compiled a list of major CFPP projects in Indonesia that reached financial closure between 2009 and 2019 [5-8] and which were funded by investment banks. We further investigated those banks which funded CFPP project companies through corporate finance [2]. This resulted in a total of 36 banks that had banking relationships with these companies, 
whether via project-related or corporate financing. This list was further verified through the websites of the corresponding project companies (project developers) and the banks, as well as public news. Unconfirmed information was not included in this study.

\section{Indonesia"s future lending challenges}

After the adoption of the Paris Agreement, the number of banks that stopped direct financing new and expansion of CFPPs increased from only three to 31 . This drastic rise occurred mostly between 2019 and 2020, in which the number shot up twofold by the end of 2020 compared to the count in 2018. Notably, 21 of the 31 banks to have stopped financing were those which had been supporting Indonesian CFPPs. Besides, some banks also imposed conditional support on existing clients. For example, Standard Chartered announced that starting in 2021, it will gradually reduce its support for existing clients whose earnings are highly dependent on coal; by 2030, it will only support clients with less than $10 \%$ dependence on thermal coal. As a result, the bank withdrew from three CFPP projects in Vietnam that would produce almost 700 million tonnes of $\mathrm{CO}_{2}$ per year, leaving the project companies to look elsewhere for financing [9]. Therefore, not only will new or expansion projects face lending challenges, but existing projects whose loans have longer-term maturities will face a higher risk of losing financial support from their present lenders. In Indonesia, existing CFPPs and new projects that have reached financial closure have no exemptions from such risks, including the plans of PLN, Indonesia's state-owned utility, for 9.5 GW of coal power expansion [4].

Globally, 25 banks had set a target year for phasing-out coal

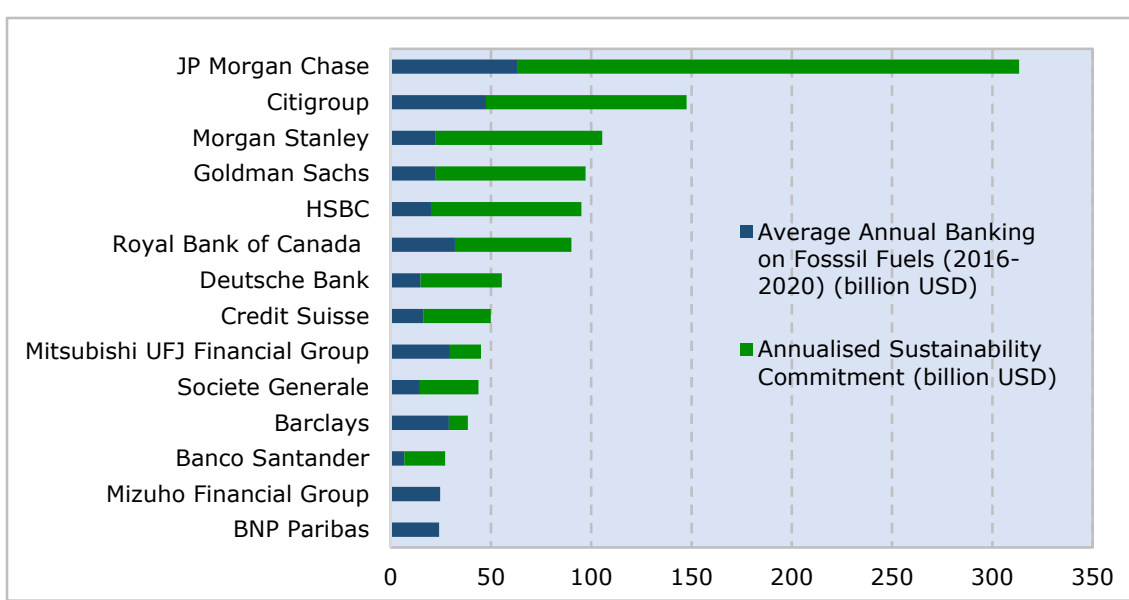

Figure 1: Banks' sustainability commitments and their fossil fuels

investments. Information on sustainability commitments were obtained from banks' official websites or reports. As of June 2021, no official

announcements were found for Mizuho Financial Group and BNP Paribas.

financing. Raising capital for Indonesian CFPPs through commercial loans will grow more difficult over time because the available lenders will become fewer and fewer. This might lead to a lending market with a higher interest rate, meaning higher costs for a project. PLN will therefore encounter higher generation costs and expensive power purchase agreements (PPAs) with Independent Power Producers (IPPs). Hence, to ensure a low electricity tariff for consumers, the government of Indonesia will need to provide higher subsidies to compensate electricity producers for those higher generation costs. In 2019, the government provided subsidies worth about USD 4 billion, and also provided nearly USD 1 billion in financial support for coal-fired power production [10]. In all, the government is providing about USD 5 billion in fiscal support each year. There is no doubt that ongoing challenges with respect to raising capital will cause the government's spending in the coal power sector to become extremely burdensome.

\section{Financing opportuni- ties for sustainability}

We reviewed bank sustainability commitments and compared them with bank behaviour towards fossil fuel companies in recent years. As these commitments differ in terms of the time frames involved, in our analysis, we annualized the commitments and financing values of 14 selected banks, presented in Figure 1. This selected list covers banks that imposed restriction on coal financing and had relationships with Indonesian CFPPs. They are also the major banks that provided the largest values of fossil fuels financing [11] and sustainability commitments. We found that the majority had committed to mobilizing sustainable financing capital greater than the amounts they had financed for fossil fuels in the past five years. Impressively, JP Morgan Chase, Morgan Stanley, and HSBC are among the banks that committed to providing sustainable financing that is about four times more than their fossil fuels financing. Not only are banks committing to ESG responsibilities but they are also aware that continuing to invest in CFPPs may not be viable over the long term, as this will likely experience lower returns or unexpected losses. Between 2017 and 2019, climate-related financial losses amounted to about USD 640 billion [12]. Hence, the greater the exposure of the financial sector to climate risk information, the greater the motivation to minimize social costs through mitigation strate- 
gies. Therefore, raising of capital for CFPPs will become more difficult than for renewables and low-carbon technologies. Furthermore, 22 of 34 banks that have been supporting Indonesian CFPPs had made official announcement on their sustainability commitments. As a result, a total amount of about 868 billion USD would be available yearly for sustainable finance. This offers opportunities for countries like Indonesia that highly depend on coal power to consider prioritizing low-carbon fuels in their longterm power development plans.

\section{Conclusions}

- As of June 2021, a total of 47 of the world largest banks had imposed a coal restriction policy; 36 of these banks have banking relationship with Indonesian coal-fired power plants (CFPPs).

- 31 banks imposed an absolute stop to financing new or expansion of CFPPs; 21 of these banks have banking re- lationship with Indonesian CFPPs.

- 25 banks imposed conditional support on existing clients; 18 of these banks have banking relationship with Indonesian CFPPs.

- 13 banks announced a target year of coal total phase-out, with the majority of these within 2030; 10 of these banks have a banking relationship with Indonesian CFPPs.

\section{Recommendations}

1. The available lenders will become fewer; raising capital for CFPPs will grow more difficult over time, including losing financial support from the present lenders. Government will need to bear the financial consequences of lending challenges; spending in the coal power sector (e.g., subsidy) will become burdensome.
2. Additionally, more banks committed to mobilizing sustainable financing capital greater than the amounts they had financed for fossil fuels. A combined total of about 868 billion USD is available yearly from 22 banks for sustainability commitments. Indonesia and other countries that are heavily dependent on coal should prioritize investment in low carbon power generation

\section{References}

[1] The Jakarta Post. Indonesia mulls net-zero emissions target by 2070, Natl. News. (2021).

[2] Coalexit. Who are the Banks \& Investors behind the Global Coal Plant Pipeline? (2019).

[3] Institute for Energy Economics and Financial Analysis (IEEFA). Financial institutions are restricting thermal coal funding, Energy Econ. Financ. Anal. (2020).

[4] Rainforest Action Network, BankTrack, Indigenous Environmental Network, Oil Change International, Reclaim Finance, Sierra Club. Banking on Climate Change - Fossil Fuel Finance Report 2020, (2020).

[5] T. Ueno, M. Yanagi, J. Nakano. Supplementary Online Material: List of projects to which China has provided public financing (2007-2013), in: Quantifying Chinese Public Financ. Foreign Coal Power Plants. (2014).

[6] Market Forces, Methodology: Full list of coal power finance

\section{Notes}

Climate Compatible Growth (CCG) programme: CCG is funded by the UK's Foreign Development and Commonwealth Office (FCDO) to support investment in sustainable energy and transport systems to meet development priorities in the Global South.
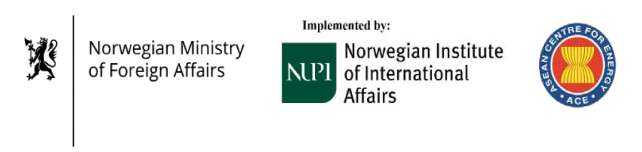

deals, in: Foreign Financ. to Indones. Coal. (2017).

[7] H. Hakko, M. Lou, Uncertain and Harmful: Japanese Coal Investments in Indonesia. (2018).

[8] Endcoal. Global Coal Public Finance Tracker. (2020).

[9] Friends of the Earth Japan, Kiko Network, Japan Center for Sustainable Environment and Society, 350.org Japan, Mekong Watch, Joint Statement: Mitsubishi Corporation increasingly isolated on coalfired power plant in Vietnam. (2019).

[10] I. Gençsü, S. Whitley, L. Roberts, C. Beaton, H. Chen, A. Doukas, A. Geddes, I. Gerasimchuk, L. Sanchez, A. Suharsono. Country Studies: Indonesia, in: G20 Coal Subsid. Track. Gov. Support to a Fading Ind. (2019).

[11] Rainforest Action Network (RAN), BankTrack, Indigenous Environmental Network (IEN), Oil Change International (OCI), Reclaim Finance, Sierra Club. Banking on Climate Chaos: Fossil Fuels Finance Report 2021. (2021).

[12] Financial Stability Board. Task Force on Climate-related Financial Disclosures Overview. (2020).

\section{Authors Information: \\ Affiliations \\ 1 ASEAN Centre for Energy (ACE), Jakarta, Indonesia \\ 2 Invite Green Consultancy, Penang, Malaysia \\ *Corresponding author \\ Email address: hyen23@gmail.com}

\section{Acknowledgements}

The authors would like to thank the Ministry of Foreign Affairs, Norway for supporting this work through the ASEAN Climate Change Project (ACCEPT) [grant numbers RAS 2805 RAS 17/0013, 2018] 